\title{
The Impact of Rural Transportation on Agricultural Development in Boki Local Government Area, Southern Nigeria
}

\author{
Margaret A. Yaro ${ }^{1}$, Asuquo E. Okon ${ }^{2} \&$ Delia B. Bisong ${ }^{1}$ \\ ${ }^{1}$ Department of Urban and Regional Planning, Cross River University of Technology, Calabar, Nigeria \\ ${ }^{2}$ Department of Geography \& Environmental Sciences, University of Calabar, Calabar, Nigeria \\ Corresponence: Margaret A. Yaro, Department of Urban and Regional Planning, Cross River University of Technology, \\ P.M.B 1123, Calabar, Nigeria. Email: mamboline2004@yahoo.com or asuquo4sec@yahoo.com
}

Received: July 15, $2014 \quad$ Accepted: September 9, $2014 \quad$ Online Published: November 26, 2014

doi:10.5539/jms.v4n4p125

URL: http://dx.doi.org/10.5539/jms.v4n4p125

\begin{abstract}
Linking areas of production with that of consumption is an effective approach for resource management and enhance productivity. Transportation remains a catalyst for efficient utilization of environmental resources for agricultural development safeguarding food security and rural livelihood. This study therefore is tailored towards assessing the impact of rural transportation on agricultural development in Boki LGA. The study adopts a questionnaire survey method for data collection as well as key informant interview and Focus Group Discussion. The study area was segmented into two based on accessibility viz, accessible and inaccessible communities. The result reveals that in inaccessible communities, common to the people is the use of head porterage (44\%) as a means of conveying their goods to the market, while in accessible areas; the common means is the use of landrover. Accessibility has therefore influenced positively the income, employment and easy access to market thereby increasing farm holdings. The paired sample test indicates that the farm holdings vary significantly in terms of farm sizes-Less than 1 hectares shows significant variation $(t=5.245 ; \mathrm{p}<0.05)$ and above 13 hectares $(\mathrm{t}=4.804 ; \mathrm{p}<0.05)$. The difference between low income and high income earnings in both areas is statistically significant $(\mathrm{t}=2.687 ; \mathrm{p}<0.05$ and $\mathrm{t}=2.856 ; \mathrm{p}<0.05)$. This result shows that transportation is vital for rural agricultural development. Hence it is recommended that rural transportation be given utmost priority to ensure sustainable food production.
\end{abstract}

Keywords: impact, transportation, agricultural development, livelihood, productivity, transformation agenda

\section{Introduction}

Transportation is a non-separable part of any society. It exhibits a very close relation to the style of life, the range and location of activities and the goods and services which will be available for consumption. It is therefore a major factor in all economic activities (Ajiboye \& Afolayan, 2009). As an economic factor of production of goods and services; transportation provides market accessibility by linking producers and consumers.An efficient transport system offering cost, time and reliability advantage permits goods to be transported quickly (Rodrigue, 2006; Tunde \& Adeniyi, 2012).

Advances in transportation, has made possible changes in the way of living and the way in which societies are organized and therefore have a great influence in the development of the economic sector. In rural setting, transport is important in the transfer of goods from the farm to the markets and such organization is ideal for local productivity improving the livelihood opportunities of the local farmers. As such transport is one of the various elemental factors in rural development and it is necessary to understand its role in rural development and particularly how it interacts alongside other factors of development, to produce the resulting structure of the rural economy and society. The availability of transports facilities in rural communities therefore affects the basic functions of production, marketing and consumption.

However, mostrural communities face transportation constraints which limit their ability to reduce their poverty, and in order to satisfy their need for greater access to health education and every possible opportunities, ease of physical accessibility and freedom of movement are top priorities (Ikporukpo, 1990). As suchmany African countries and other developing economies will not be able to develop industries based on their primary agricultural products, provide adequate employment or sustain current levels of foreign exchange earnings from 
their exports. Unfortunately, the transportation system needed to evacuate these goods is not available and adequate (Richardson, 1999).

In Nigeria, which is typically an agrarian nation with more than 70 percent of the population residing in the rural areas, the inhabitants are mostly farmers engaged in agriculture producing goods such as palm oil, yam, garri, Kola nut, rice, beans, cocoa and so on; that are consumed in the cities and most of the agricultural raw materials used by the industries, the majority of the goods to be transported are by nature often bulky, low price, perishable.

In the last two decades, little or no attention was being given to the agricultural sector because of the discovery of the crude oil, until the advent of the rural transformation policy which is the bedrock for the actualization of the Millennium Development Goals (MDGs) and vision 2020. The transformation agenda of the Federal Government involves improvements in the supply of inputs; increase in the output of commodities and a strong coordination for development of agricultural business (Nwajiuba, 2010).

Poor accessibility in the rural areas poses a great challenge to actualize rural development efforts in Nigeria through agricultural reforms, as it has continued to make most of the rural areas to find difficulties in accessing markets for their produce and vice versa (Ajiboye and Ayantoyinbo, 2009; Ajiboye and Olaogun, 2006, ukwu, 1990),). It is impossible for buyers to reach some of the communities in Boki during the rainy season due to the bad terrain. With the effort of the state Government in recent times to construct rural roads, it is important to find out if this effort has made any impact in agricultural development and to assess the difference in the inaccessible areas.

\subsection{Study Area}

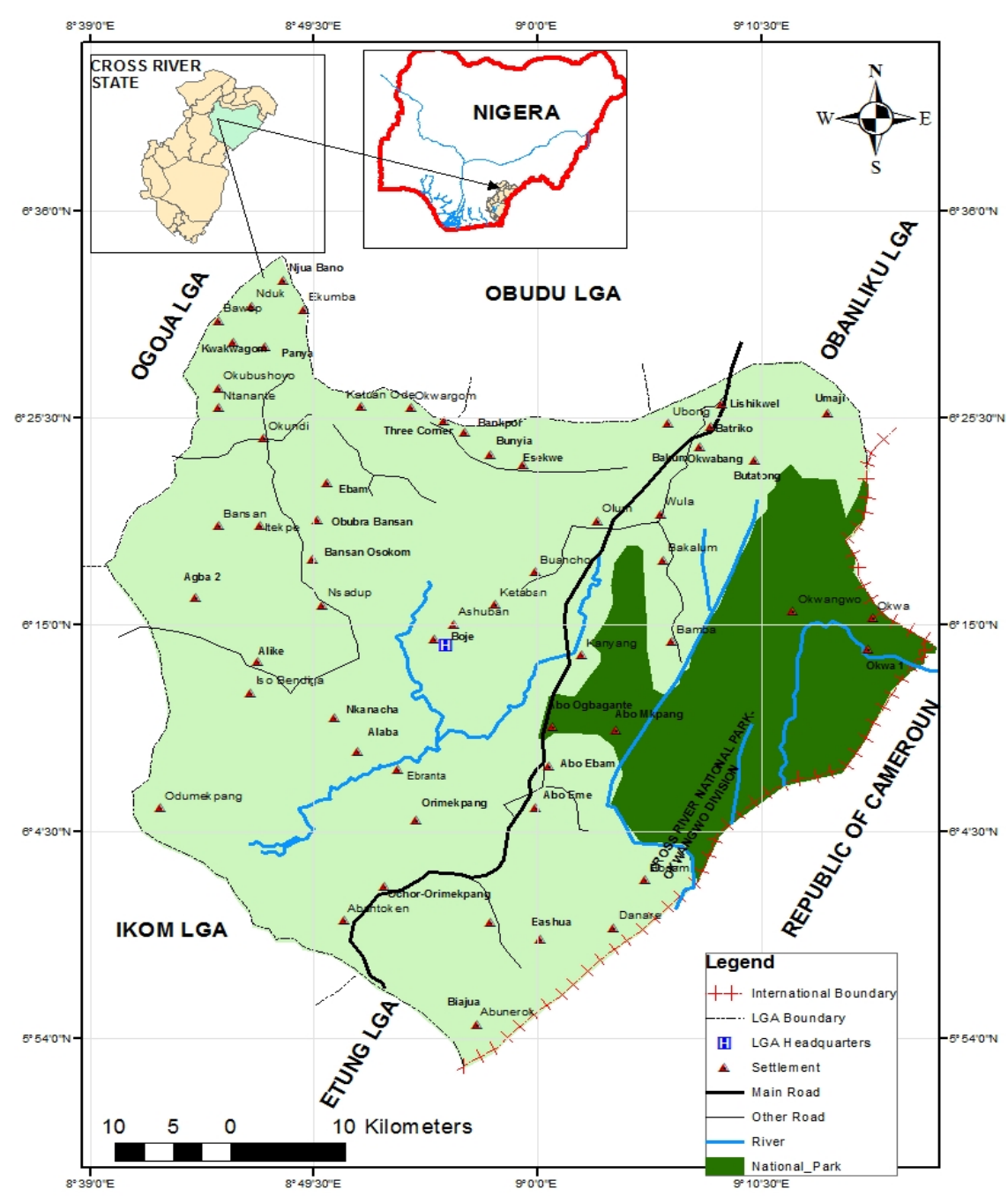

Figure 1. The study area 
Boki Local Government Area (LGA) is the second largest LGA of Cross River State in terms of landmass $\left(344,952 \mathrm{~km}^{2}\right)$. It is located between latitude $5^{0} 52^{\prime}$ and $6^{\circ} 34^{\prime} \mathrm{N}$ and Longitude $8^{0} 40^{\prime}$ and $9^{0} 20^{\prime} \mathrm{E}$. The study area is bounded in the North by Obudu and Obanliku Local Government Area, to the South by Ikom, to the West by Ogoja and to the East by Cameroon Republic (Figure 1). Boki is situated at the southern end of the eastern highland border of Nigeria with Cameroon. It is within the semi-equatorial (Monsoon) climate type with annual rainfall ranges between $2500 \mathrm{~mm}$ to $3000 \mathrm{~mm}$.

The study area is found within the tropical rainforest belt of Nigeria with closed canopy forest and made up of layers broad leaf evergreen tree species. Boki has an undulating terrain with hill locks in some areas. The soil is loamy in nature rich in farming. Hence, the people of Boki are predominantly farmers.

\section{Methodology}

A survey design was adopted in this study by selecting and studying samples chosen from the population to discover the distribution and interrelationship between variables under investigation. The survey research depends basically on questionnaire, site observations and oral interviews as instruments for data collection.

Data for this study were collected from the primary and secondary sources. Primary sources of data were obtained from site observation, questionnaire administration and oral interview. Secondary sources of data on the other hand were obtained from extant literature.

The sample communities were categorized into two based on ease of access (accessible and inaccessible communities). The criteria used for categorization include the access by taxi (cars) and the ability to carry load without difficulties in line with the local criteria. The Information elicited using the instruments include income of farmers, cost of farm commodities before and after construction of road, predominant mode of transportation in the sample communities as well as transportation contribution to agricultural development were equally capture using the questionnaire.

Key informant interviews and Focus Group Discussion (FGD) were carried out. Interviews were also conducted in the course of data collection, thus, enabling the researcher to have face-to-face interaction with buyers, sellers and drivers who plied the route where this study was conducted. Sampled communities were considered as accessible communities and inaccessible communities. Easily accessible communities include Abo, Boje, eastern Boki, Osokom 1 where all types of vehicles can reach and inaccessible communities include Bashu, Okwangwo and Okwa where only bikes can reach. Accessible communities have a total population of 12,472 persons, while inaccessible with a population of 12,303 . Therefore the population size forms the basis for the choice of the communities. The sample size of 400 respondents from accessible and equal number of respondents (400) from inaccessible communities were determined using Yaro Yamane's formula for finite population as expressed below:

$$
n=\frac{N}{1+N(e)^{2}}
$$

Where $\quad \mathrm{n}=$ the sample size

$\mathrm{N}=$ the finite population

$\mathrm{e}=$ level of significance (limit of tolerable error $=0.05$ )

$1=$ unit (a constant)

Simple Random Sampling Technique was adopted in questionnaire administration, before then stratified sampling technique was equally adopted to select the sampled communities of the study area. Out of the 400 questionnaire distributed, (800) from the two categories of communities, 388 copies were received from the accessible communities which shows $97 \%$ return rate. In the inaccessible communities 368 copies were received which shows $92 \%$ return rate. The analysis is based on this return rate. The analysis was carried out using simple percentage and paired sample t-test

\section{Result}

\subsection{Means of Transportation in the Study Area}

Table 1 shows that about $16.8 \%$ of the people convey their farm commodities on their head, $3 \%$ of the respondents used bicycle to transport their farm commodities from the farm to the market. Also, majority of the farmers $(26.3 \%)$ use Lorries followed by motorcycle used by $25.3 \%$ as the means of transporting their farm produce. On the other hand, motor car, mini buses and lorriestipper are used by $2.6 \%, 6.4 \%$ and $19.8 \%$ of 
farmers in transporting their produce (Figure 2). In inaccessible communities, majority of the people (44\%) use head porterage as a means of conveying their agricultural produce, while $33.2 \%$ use motorcycle.

Table 1. Means of transportation by road

\begin{tabular}{lllll}
\hline & \multicolumn{2}{l}{ Accessible communities } & \multicolumn{2}{l}{ Inaccessible communities } \\
\hline Option & Frequency & $\mathbf{9}$ & Frequency & $\%$ \\
Head (Porterage) & 65 & 16.8 & 164 & 44.6 \\
Bicycles & 12 & 3 & 48 & 13.0 \\
Animal carriage & 0 & 0 & 0 & 0 \\
Motor cycle & 98 & 25.3 & 122 & 33.2 \\
Motor cars & 10 & 2.6 & & 0 \\
Pick-up/landrover & 101 & 26 & 34 & 9.3 \\
Mini Bus & 25 & 6.4 & 0 & 0 \\
Lorries/Tipper & 77 & 19.8 & 0 & 0 \\
Total & $\mathbf{3 8 8}$ & $\mathbf{1 0 0}$ & $\mathbf{3 6 8}$ & $\mathbf{1 0 0}$ \\
\hline
\end{tabular}

Source: Researchers' field survey, 2014.

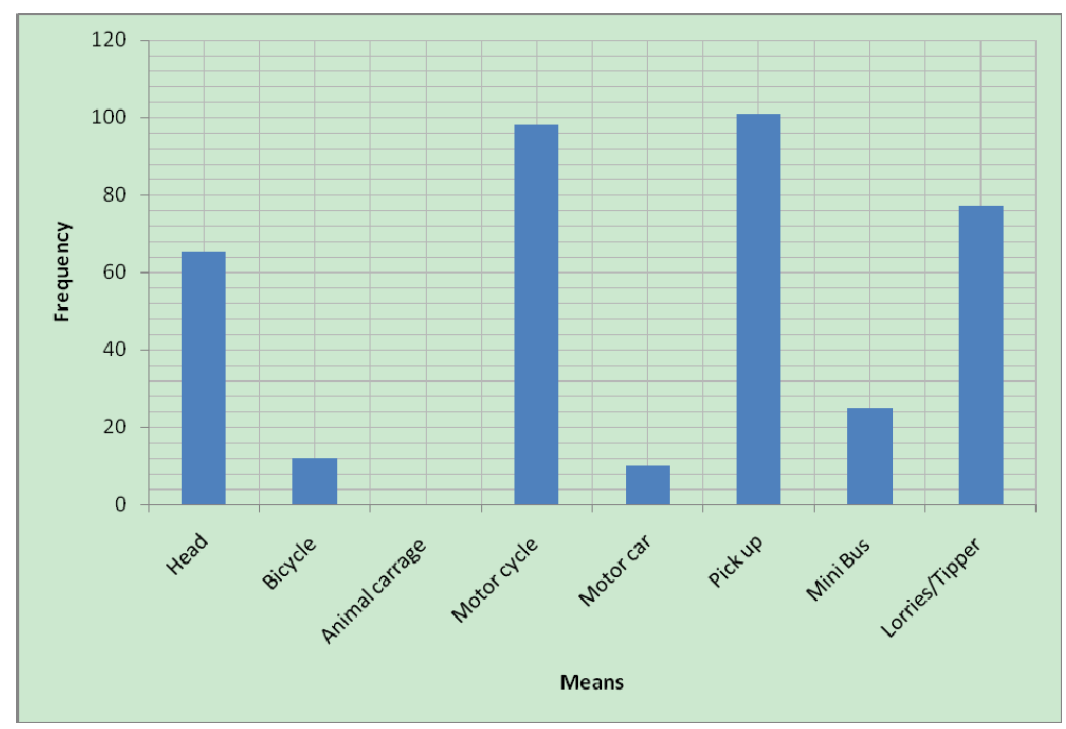

Figure 2. Means of transportation by road

\subsection{Impact of Transportation on Agriculture}

The contribution of transportation to agricultural development as presented in Table 2 shows that $23 \%$ of the farmers through improved accessibility to their communities has improved their income status, $16.8 \%$ of the respondents (farmers) indicates that their farm produce attract high demand due to improved access; $15.5 \%$ also show that improved transport flow in their communities have given them employment in agricultural; while 14.9 have easy access to market for their produce among others. In remote areas only $4.1 \%$ have improved income from the difficult access in the area.

The responses imply that communities with good accessibility and good transportation network have competitive advantage in the area of income, demand (number of customers) and employment opportunities (Figure 3). 
Table 2. Transportation contribution to agricultural development

\begin{tabular}{|c|c|c|c|c|c|c|c|c|c|c|c|}
\hline \multirow[b]{2}{*}{ Options } & \multicolumn{6}{|c|}{ Accessible communities } & \multicolumn{5}{|c|}{ Inaccessible communities } \\
\hline & Abo & Boje & $\begin{array}{l}\text { Eastern } \\
\text { Boki }\end{array}$ & Osokom 1 & Total & $\%$ & Bashu & Okwangwo & Okwa & Total & $\%$ \\
\hline Access to farm input & 5 & 5 & 9 & 4 & 23 & 5.9 & & & 0 & & 0 \\
\hline Improved income & 22 & 32 & 22 & 16 & 92 & 23.7 & 10 & 6 & 0 & 16 & 4.1 \\
\hline Easy access to farm & 7 & 9 & 6 & 4 & 26 & 6.7 & 2 & 2 & 0 & 4 & 1 \\
\hline $\begin{array}{l}\text { Employment } \\
\text { opportunity }\end{array}$ & 15 & 18 & 17 & 10 & 60 & 15.5 & & & 0 & 0 & 0 \\
\hline Accessibility to market & 13 & 15 & 17 & 13 & 58 & 14.9 & & & 0 & 0 & 0 \\
\hline $\begin{array}{l}\text { High demand of farm } \\
\text { products }\end{array}$ & 13 & 25 & 14 & 13 & 65 & 16.8 & & & 0 & 0 & 0 \\
\hline Others & 10 & 14 & 5 & 15 & 44 & 11.3 & & & & 0 & 0 \\
\hline Total & 85 & 118 & 90 & 75 & 368 & 94.8 & 12 & 8 & 0 & 20 & 5.2 \\
\hline
\end{tabular}

Source: Researchers' field survey, 2014.

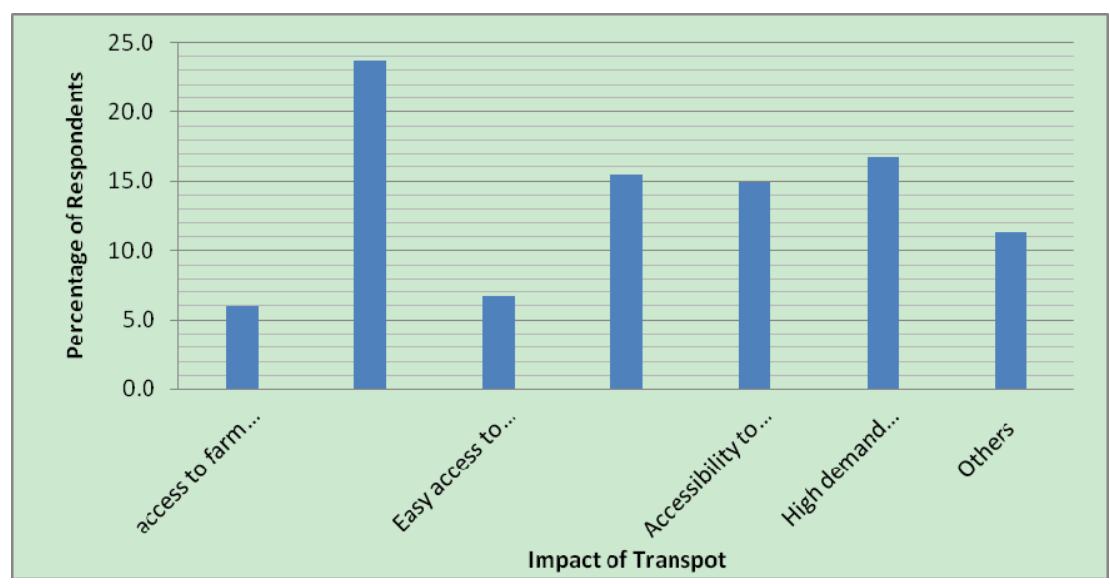

Figure 3. Farmers response on impact of rural transportation on agriculture

\subsection{Impact of Transport on Farm Sizes}

The farm sizes in accessible and inaccessible communities of the study area as presented in Table 3 reveals that $15.5 \%$ of farmers in accessible communities owned 13 hectares of farm land and above as against $2.4 \%$ of farmers within inaccessible communities. Also, $27.1 \%$ of the farmers in accessible communities occupy 10-12 hectares of farmland as against $4.1 \%$ of the farmers in inaccessible communities. Within the mean range of farm sizes in the area, $20.9 \%$ of farmers in accessible communities like in Abo, Boje, Eastern Boki and Osokom1 holds 7-9 hectares as against Bashu, Okangwo and Okwa (inaccessible communities) with only $7.3 \%$ of farmers holding 7-9 hectares of farmland, while $14.7 \%$ of the farmer inaccessible communities as and $37.5 \%$ in inaccessible communities holds less than one hectares of farmland (Figure 4).

The paired sample test in Table $3 \mathrm{~b}$ indicates that the farm holdings vary significantly in terms of farm sizes. For instance Less than 1 hectares shows significant variation $(\mathrm{t}=5.245 ; \mathrm{p}<0.05)$ and above 13 hectares $(\mathrm{t}=4.804$; $\mathrm{p}<0.05)$; however, those holding $4-6$ hectares is not statistically significant $(\mathrm{t}=0.338 ; \mathrm{P}>0.05)$. This implies that farmers in accessible communities mostly engage in commercialize agriculture because of the advantage of roads in the area whereas communities with inaccessible opportunities commonly engage in subsistence agriculture which can easily leads them to financial handicap. 
Table 3a. Farm size in accessible and inaccessible areas in hectares

\begin{tabular}{|c|c|c|c|c|c|c|c|c|c|c|c|}
\hline \multirow[b]{2}{*}{ Farm size in hectares } & \multicolumn{6}{|c|}{ Accessible communities } & \multicolumn{5}{|c|}{ Inaccessible } \\
\hline & Abo & Boje & Eastern Boki & Osokom1 & Total & $\%$ & Bashu & Okangwo & Okwa & Total & $\%$ \\
\hline Less than 1 hectare & 16 & 21 & 10 & 10 & 57 & 14.7 & 56 & 41 & 41 & 138 & 37.5 \\
\hline $1-3$ & 5 & 4 & 6 & 14 & 29 & 7.5 & 29 & 38 & 38 & 105 & 28.5 \\
\hline $4-6$ & 10 & 18 & 16 & 12 & 56 & 14.4 & 21 & 24 & 29 & 74 & 20.1 \\
\hline $7-9$ & 12 & 34 & 15 & 20 & 81 & 20.9 & 6 & 5 & 16 & 27 & 7.3 \\
\hline $10-12$ & 22 & 33 & 32 & 18 & 105 & 27.1 & 3 & 4 & 8 & 15 & 4.1 \\
\hline 13 and above & 11 & 20 & 13 & 16 & 60 & 15.5 & 3 & 2 & 4 & 9 & 2.4 \\
\hline Total & 76 & 130 & 92 & 90 & 388 & 100.0 & 118 & 114 & 136 & 368 & 100.0 \\
\hline
\end{tabular}

Source: Researchers' field survey, 2014.

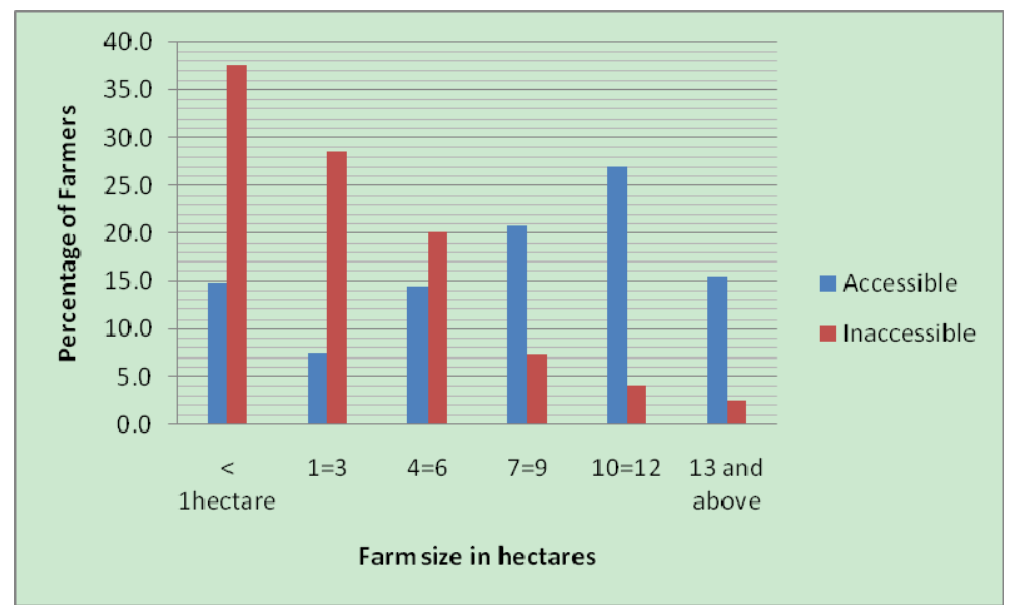

Figure 4. Accessibility and size of farm holding

Table 3b. Pared sample test

\begin{tabular}{llllllll}
\hline Pairs & Farm Size & Mean & Std. Deviation & Std. Error Mean & t & df & Sig. (2-tailed) \\
\hline Pair 1 & Less than 1 hectare & -30.3 & 10.01665 & 5.78312 & -5.245 & 2 & 0.034 \\
Pair 2 & $1-3$ & -30.0 & 5.2915 & 3.05505 & -9.82 & 2 & 0.01 \\
Pair 3 & $4-6$ & 11.3 & 15.69501 & 9.06152 & 1.251 & 2 & 0.338 \\
Pair 4 & $7-9$ & 24.0 & 5 & 2.88675 & 8.314 & 2 & 0.014 \\
Pair 5 & $10-12$ & 11.7 & 5.50757 & 3.1798 & 3.669 & 2 & 0.067 \\
Pair 6 & 13 and above & -10.0 & 3.60555 & 2.08167 & -4.804 & 2 & 0.041 \\
\hline
\end{tabular}

\subsection{Accessibility and Cost of Farm Produce}

The cost of farm produce in accessible and inaccessible communities of the study area is presented in Tables 4 . The data indicates that the cost of farm produce in accessible communities is higher engendered by high rate of demand due to increase in the number of customers. Over $22.4 \%, 12.9 \%$, and $11.0 \%$ of the farmers were of the view that, the costs of their farm products have increased ranging between $\$ 6000-9000, \$ 10,000-13,000$ and 18000-21,000 respectively (In Nigeria Naira) as compared with communities that are not accessible whose farm commodities are of low demand within the price range below that of the accessible communities. Moreover, the responses of $6.2 \%$ of the same population were of the opinion that farm commodities such as cocoa in accessible communities is sold between the price range of $\mathrm{N} \mathrm{2,} 2000$ and above which upturned that in inaccessible communities where no bag of cocoa can be sold at the stipulated prices of N 22,000 and above. By implication Farmers face the challenge of marketing perishable goods

The result in Table 4 implies that without good transportation network some communities in the area would not have felt the impact of patronage of the farm commodities. A line graph of figure 5 was used to show the difference in cost of products in both accessible and inaccessible communities. 
Table 4. Cost of farm products in accessible and inaccessible communities of the study area

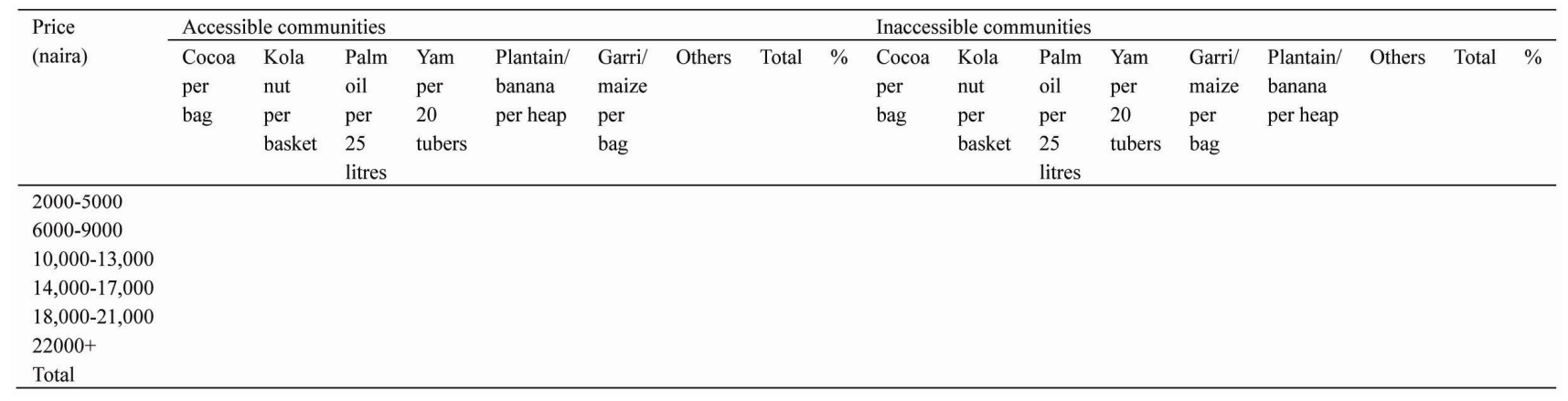

Source: Researcher's field survey, 2014.

\subsection{Income Status of Farmers}

Income per month for accessible and inaccessible communities is presented in Table 5. This shows that over $43.6 \%$ of the farmers in inaccessible communities and only $4.9 \%$ in accessible communities earn between $\$ 1000$ - $\$ 5000$. The income range of N6000-10000 is earned by $34.3 \%$ of farmers in inaccessible area. Equilibrium earning set in in the range of N11, 000-15,000 where both communities have equal number of earners. At higher income range. Those in accessible communities are better off. For instance N21, 000 and above is earned by $45 \%$ in accessible communities and only $1.9 \%$ in inaccessible communities.

The paired sample test shows that the difference between low income and high income earnings in both areas is statistically significant $(\mathrm{t}=2.687 ; \mathrm{p}<0.05$ and $\mathrm{t}=2.856 ; \mathrm{p}<0.05)$

Table 5a. Incomes per month the two communities in Naira (N)

\begin{tabular}{lllll}
\hline Amount (N) & $\begin{array}{l}\text { Accessible } \\
\text { Frequency }\end{array}$ & $\mathbf{\%}$ & $\begin{array}{l}\text { Inaccessible } \\
\text { Frequency }\end{array}$ & $\mathbf{\%}$ \\
\hline $1000-5000$ & 19 & 4.9 & 169 & 43.6 \\
$6000-10000$ & 30 & 7.7 & 133 & 34.3 \\
$11000-15000$ & 55 & 14.2 & 59 & 15.2 \\
$16000-2000$ & 109 & 28 & 20 & 5.2 \\
$21000 \&$ above & 175 & 45 & 7 & 1.8 \\
\hline Total & $\mathbf{3 6 8}$ & $\mathbf{1 0 0}$ & $\mathbf{3 6 8}$ & $\mathbf{1 0 0}$ \\
\hline
\end{tabular}

Source: Researcher's field survey, 2014.

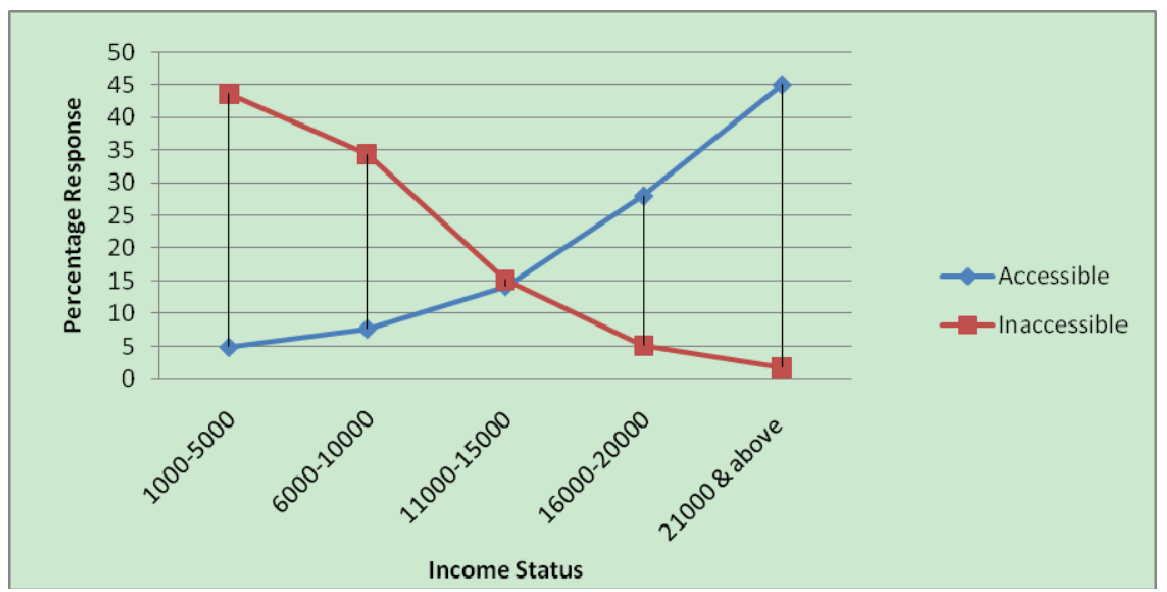

Figure 5. Income status of farmers 
Table 5b. Pair sample test

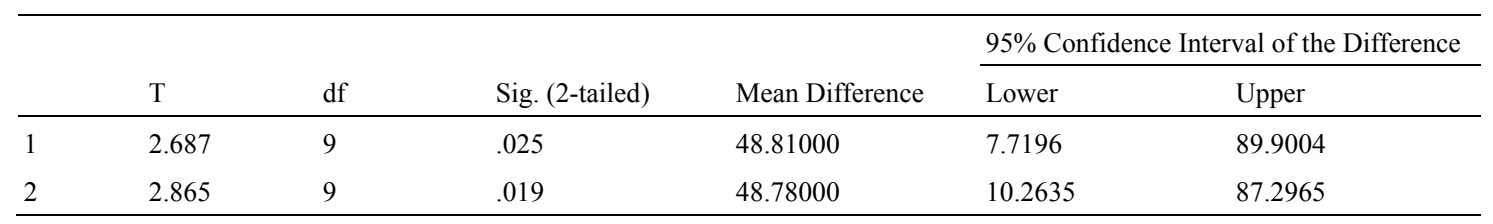

\section{Discussion of Findings}

The study revealed the agricultural activities in communities with good transportation system flows without any mobility hindrance.The predominant means of road transportation include: Pick-up, motorcycle, Lorries/Tippers as well as Head Porterage, Moreover, means of road transportation like head porter age, bicycles, motorcycle as evident in the data are operated mostly in the inaccessible communities. This mean that farm products in such areas are being taken to nearby communities where all these farm commodities are to be sold and are often sold at very cheaper rate because of the cost, fear and stress of conveying the commodities back home. The poor patronage of this farm commodities leads to wastage of farm commodities. But the reverse is the case in communities with good transportation system whose level of patronage is attractive.

Inaccessibility may therefore affect food availability and food security. Bureau of public enterprise, (2003) argued that the problem of road transport sub-sector has suffered from the effect of past shortage of resources. The decline in the number of commercial vehicle transporting farmers and traders and their goods to and from the market militates against development. As observed by Iwuchukwu and Igbokwe (2012), policies of government on rural transformation through agriculture are yet to be given implementation plans. The agricultural transformation agenda of the government among other things seeks to: Secure food and feed needs of the nation; Enhance generation of national and social wealth through greater export and import substitution; Enhance capacity for value addition leading to industrialization and employment opportunity; Make for efficient exploitation and utilization of available agricultural resources; Enhance the development and dissemination of appropriate and efficient technology for rapid adoption; Achieve self-sufficiency in rice production; and Achieve self-sufficiency in fertilizer production (Ukaoha, 2012), yet the goals are yet to be achieved.

The movement of agricultural goods between the area of production (Mostly rural areas) and area of consumption (usually urban centres) is driven by efficient transport system. According to Adesanya et al (2000), rural travel and transport in most rural areas in Nigeria still take place with great difficulties thereby compounding and worsening the problem of rural productivity and rural poverty. More so, Adeyanju (2009) identified that effort have however been made in recent times to address the rural road problem in the country in order to proffer solution. Without addressing these issues rural development remains at brink and poverty alleviation as well food security to achieve MDGs may not be achievable.

Those areas with good transportation network cultivate reasonable portion (hectares) of farm land are occupied to meet the demand in of the urban and rural areas, whereas the farm lands in inaccessible areas where there are challenges of transportation is at subsistence level. However, In the case of commercial agricultureneed to be treated with caution to avoid unsustainable land use. This is because the rate and patterns of loss of tropical moist forest cover to agriculture is alarming (Nathaniel et al., 2012; Bisong, 2004, 2007; Bisong, 2003; Bisong \& Arokoyu, 2003).

The introduction of the rural road construction scheme of the State Government have really boosted the level of sales of farm commodities which have equally boost income per month of over $50 \%$ of farmers. According to Sule (2003), investments in rural roads have significant potential for the use of local resources, create decent jobs, support the local economy and strengthen local commerce and social development The direct consequence of investing in rural roads is the generation of jobs, incomes and business opportunities, particularly if the development and maintenance of the rural road is targeted in favour of local resources based methods. The improvement of rural roads to goods and services and production and productivity enhancing impact those further contribute to sustainable poverty reduction and local economic and social development.

\section{Conclusion}

It is quite obvious, that transportation is responsible for the development of agriculture and other industries right from the past to the present by meeting travel requirement of people, goods and services from areas of production to areas of consumption. In an agrarian culture like Nigeria the impacts of transportation spans different areas of economic, environment, social, agricultural, political background. For ustainable resource 
management and productivity, transportation is therefore a sine quanon.

In view of the above, the researcher hereby recommended that;

$>$ Due to perishability, seasonality, Bulkiness of agricultural products, agriculture cannot thrive without flexible transportation system, effective transport system is important.

$>$ Rural transport system linking farms and markets should be given priority

$>$ Incentives should be made available to farmers.

$>$ Sustainable land use planning is important for sustainable productivity

\section{References}

Ajiboye, A. O., \& Afolayan, O. (2009). The impact of transportation on agricultural production in a developing country: a case of kolanut production in Nigeria.

Ajiboye, A. O., \& Ayantoyinbo, B. B. (2009). Analysis of Transportation and Distribution Problems of Agricultural Products Marketing in Sub Saharan Region: An Application to Kolanut. Journal of Technology, Entrepreneurship and Rural Development, 4(1), 188-200.

Ajiboye, A. O., \& Olaogun, O. B. (2006). Analysis of mobility characteristic of Rural Areas in Sub-Saharan Region: Case from Nigeria. The Interface, A BiannualJournal of Management, 2(2), 75-92.

Bisong, F. E. (2007a). Land Use and Deforestation in the Rainforest of South-Eastern Nigeria (1972-2001). The Nigerian Geographical Journal, 5(1), 19-28.

Bisong, F. E. (2007b). Participatory Land Use Planning for Community Based Forest Management in South-Eastern Nigeria. Lwati, a Journal of contemporary research, 4.

Bisong, F. E., \& Arokoyu, S. B. (2003). Agricultural Land use Modelling and Deforestation: An Analysis of Proximate Drivers in South-eastern Nigeria. Ghana Educational Media and Technology Association Journal, 5, 47-64.

Nwajiuba, C. (2012). Nigeria's agricultural agenda and food security challenges.

Tunde, A. M., \& Adeniyi, E. E. (2012). Impact of Road Transport on Agricultural Development: A Nigerian Example. Ethiopian Journal of Environmental Studies and Management, 5(3). http://dx.doi.org/10.4314/ejesm.v5i3.3

Ukaoha, K. (2012). 2012 Nigeria Agriculture Budget Appraisal. Nigeria: National Association of Nigerian Traders - NANTS.

\section{Copyrights}

Copyright for this article is retained by the author(s), with first publication rights granted to the journal.

This is an open-access article distributed under the terms and conditions of the Creative Commons Attribution license (http://creativecommons.org/licenses/by/3.0/). 